\title{
Cutting student costs
}

\section{London}

ThE Universities Funding Council (UFC) has unveiled a new funding system that aims to expand the number of British undergraduates while driving down the cost of teaching each student. The new system, which comes against the backdrop of the University of Edinburgh's facing financial disaster because it has too few students for the size of its faculty, will encourage universities to take on large numbers of 'fees-only' students without UFC funding by promising to reward those that do so with more UFCfunded student places in subsequent years.

This latest funding plan replaces last year's abortive 'competitive bidding' system, which sought to reduce the cost of teaching each student by making the universities bid against one another for funded undergraduate places. The idea was that universities

LONDON ZOO _

Attempts to avoid closure

\section{London}

LONDON Zoo is scheduled to present a rescue plan today (11 April) to the Department of the Environment in a last-ditch attempt to avoid closure. The plan involves giving up some of the zoo's larger animals and transforming it into a centre for conservation education.

The cost of the change-over is estimated at about $£ 12$ million, most of which would come from private sponsorship. The government will be asked to contribute £3-4 million towards the implementation of the plan, but previous experience suggests it will be reluctant to agree. It offered a once-only grant of $£ 10$ million in 1988 , but has since given no further aid to the zoo, which last year ran up a $£ 4.9$ million operating deficit. The government's handling of the zoo's financial predicament contrasts sharply with its behaviour towards other London institutions. Both the Natural History Museum and the Royal Botanic Gardens, Kew receive state subsidies.

Now the zoo's 1988 grant is half gone, and rather than see this fund shrink further, the Zoological Society of London, which administers the zoo and leases the 47-acre (19-hectare) site from the Department of the Environment, may choose to divert it elsewhere. This would mean closing the zoo and transferring a proportion of its 8,000-strong stock of animals to its nearly self-supporting, 600-acre freehold site at Whipsnade, about 35 miles north of London. The fate of the rest is undecided, and might depend on the extent to which any further government subsidy can be used to buy time for suitable arrangements to be made with other zoos.

HenryGee that were eager to expand would offer to teach students more cheaply. The system failed, however, when universities tried to circumvent the system by submitting the vast majority of their bids for more students at the maximum prices suggested by the UFC - in effect operating as a cartel.

The new system will be more difficult to subvert. Any university that refuses to take on more students funded only through the minimal teaching fees charged to local education authorities $(£ 2,650$ per science student in 1991-92) will find their plans for growth stalled. Because almost all the universities wish to expand, the UFC believes that most will decide to take on more fees-only students, increasing the proportion of British undergraduates taught without UFC funding from the current 12 per cent. Those universities recruiting the most feesonly students will be favoured when the UFC comes to allocate the extra 25,300 funded places it plans to distribute between $1992-$ 93 and 1994-95.

Although the Committee of ViceChancellors and Principals (CVCP) has yet to meet to discuss the new system, most vicechancellors reject the UFC's central assumption that teaching quality can be maintained while reducing the average cost of teaching each student. Universities have increased their efficiency as far as possible, they argue, and the accusations of poor financial management made by the government during the 1980 s do not now apply.

But the vice-chancellors' desire to present the universities as efficient, well-managed institutions may be undermined by the revelation that unless drastic action is taken, the University of Edinburgh will have a $£ 5$.4million deficit in 1990-91 - much worse than the $£ 4$ million deficit it had predicted previously. And this is in addition to an accumulated deficit that totalled some $£ 5$ million at the end of 1989-90.

Sir David Smith, Edinburgh's principal, admits that the university has been "living beyond its means for a number of years", and blames defects in accounting for the previous failure to recognize the true extent of the problem. Edinburgh's difficulties stem from the fact that it has only 10.1 students for each member of staff - the lowest ratio in the country. But the university has now agreed an emergency package of measures to increase teaching efficiency, under close scrutiny from UFC officials.

Smith says that Edinburgh will now take on ten per cent more students than it had planned in 1991-92, on a fees-only basis, and will continue a freeze on staff appointments introduced last year.

Edinburgh aims to break even within three years, but before then it may be forced to sell some $£ 5$ million worth of its $£ 250$ million assets, which are tied up in university-owned buildings and land. Edinburgh lecturers may

\section{Car-eating bacteria}

Munich

WHAT can be done with two million unwanted Trabants? Eastern Germans are rapidly scrapping the ubiquitous 2-stroke East German cars now that reunification has opened the borders to other automobiles, and they pose a problem in solidwaste disposal. But a group of German chemists believe they have a solution. Peter

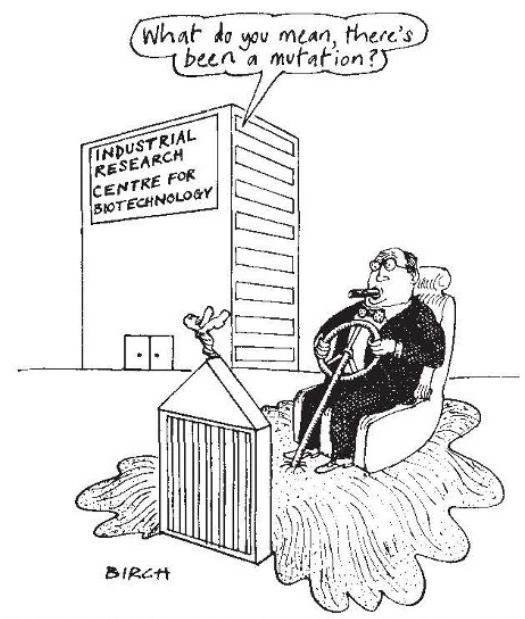

Lietz and his coworkers at the Industrial Research Centre for Biotechnology in East Berlin are working on isolating strains of bacteria that will be able to digest the resins that make up the car's $650-\mathrm{kg}$ body, reducing it to just $10 \mathrm{~kg}$ of residual biomass.

The East Berlin group holds patents on a strain of penicillium bacteria known as Penicillium jantinellum that can break down the cellulose in the Trabant. They are now tackling the problem of breaking down the polyphenol resins that are another major component in the car. Once they have isolated an appropriate strain using conventional selection techniques or possibly genetic engineering, they will put it to work in a complex multistep process involving heat and mechanical breakdown as well as digestion.

Trabbis, as the cars are still affectionately known, will continue to be produced at the rate of 150 a day until the production plant in Zwickau is shut later this month.

Steven Dickman

also be asked this year to take a pay increase lower than that agreed nationally between the CVCP and the Association of University Teachers.

Edinburgh's admission of poor financial planning follows the finding by a University of Bristol financial committee that Bristol's unexpected $£ 4.4$ million deficit in 1989-90 was the result of poor financial control. The UFC has made Bristol's budget for 1991-92 provisional on the university's improving its financial management. PeterAldhous

The CVCP this week publishes a booklet, The State of the Universities, which claims that the current pressure to expand while cutting costs will damage the universities irreparably. 